\title{
Survey and Solutions for the Current Status of Quality Control in Small Hospital Laboratories
}

Jae Han Kim ${ }^{1}$, Eun Jin Choi ${ }^{1}$, Gyuhyeon Hwang $^{2}$, Jae Ho Lee ${ }^{2}$, and Mi-Soon $\mathrm{Han}^{1}$

${ }^{1}$ Department of Laboratory Medicine, U2 Clinical Laboratories, Jangwon Medical Foundation; ${ }^{2}$ Department of IT Research Institute, U2Bio Co. Ltd., Seoul, Korea

Corresponding author: Mi-Soon Han Department of Laboratory Medicine, U2 Clinical Laboratories, Jangwon Medical Foundation, 68 Geoma-ro, Songpa-gu, Seoul 05755, Korea Tel: $+82-2-910-2103$ Fax: $+82-2-910-2190$ E-mail: loveelohim9083@ hanmail.net

\begin{abstract}
Background: To prevent medically significant errors, hospital laboratories must perform thorough statistical quality control (QC) procedures. We surveyed the QC status of small laboratories and created new statistical QC software that they can easily use for improving QC.

Methods: A questionnaire on the status of external and internal QC was created and sent to clinics and hospitals with small-scale laboratories. We then created QC software that can be downloaded and installed for free.

Results: External quality assessments were performed in 32\% of the clinics (22 of 66) and $52 \%$ of the hospitals (12 of 23). Seventy-three percent of all institutions (66 of 90) carried out an internal quality assessment based on their own guidelines, mostly using commercialized QC materials. However, only $52 \%$ of clinics and $23 \%$ of hospitals used their own acceptable range instead of the manufacturer's expected range. In addition, the proportion of manual QC management reached 52\% in clinics and 82\% in hospitals. The QC software we designed covers all the basic functions of statistical QC and aims to improve the quality of laboratories. Conclusions: We obtained basic data on the current status of external and internal QC in small-scale laboratories using this survey. Furthermore, we suggested that new QC software may actually help to improve QC of small laboratories.
\end{abstract}

(J Lab Med Qual Assur 2018;40:101-108)

Key Words: Hospital laboratories, Quality control, Software, Health care quality assessment

Received January 22, 2018, Revision received March 26, 2018, Accepted April 15, 2018

\section{INTRODUCTION}

Laboratory medicine plays an essential role in disease diagnosis in the medical field. It allows us to measure specific components of biological samples from the human body, thereby diagnosing diseases, determining therapeutic effects, and predicting prognosis. As a rule, the more advanced the diagnostic test is, the more likely that the patient's medical care will be reliant on the test results [1]. For this reason, laboratories must perform strict quality control $(\mathrm{QC})$ procedures to avoid reporting erroneous results.

Statistical quality control (SQC) techniques are considered the best approach to assure quality in laboratories [2]. Large-scale laboratories are now performing complex SQC procedures using commercially available software via specific providers or proprietary software developed through costly outsourcing. In contrast, small-scale laboratories often have insufficient labor or funding to automate $\mathrm{QC}$ processes. The $\mathrm{QC}$ management in small-scale laboratories is performed manually using excel spreadsheets, not using computerized QC software. This implies the possibility that internal QC is not performed properly or produces frequent errors because of manual operation.

We surveyed the QC status of clinics and hospitals 


\section{Journal of LABORATORY MEDICINE and QUALITY ASSURANCE}

Jae Han Kim et al • Quality Control Status of Small-Scale Laboratories

with small-scale laboratories, which are expected to have problems with achieving adequate QC. We also attempted to design new QC software that consists of basic essential functions and is simple and free to use, specifically for small-scale laboratories.

\section{MATERIALS AND METHODS}

\section{Status Survey}

1) Sample

In this study, we defined a small-scale laboratory as any laboratory where the number of clinical laboratory technologists was five or less. We randomly selected 228 out of all our clients (1,824 clinics or hospitals), adopting a stratified sampling strategy. All institutions were divided into five groups according to their region, and the number of survey participants in each group was allocated in proportion to the number of affiliated institutions. We explained the purpose of the study and the intended use of the collected data to the head of each institute. Then, this survey was conducted with informed consent. In addition, all private information of the institution was anonymized.

\section{2) Questionnaire}

The questionnaire comprised 21 items asking about the status of external and internal QC assessment of the institute as well as general information.

\section{Development of New Internal Quality Control Software}

1) Intended use

We planned for the new QC software to handle both quantitative and semi-quantitative measurement procedures to help small laboratories improve their QC processes. This program automated several SQC processes, thereby allowing users to quickly and easily perform various QC tasks. It met the requirements of the Korean Laboratory Accreditation Program of the Korea Laboratory Medicine Foundation [3].

\section{2) Development tools}

The QC software was created using the Microsoft Visual Studio 2010 Integrated Development Environment Visual

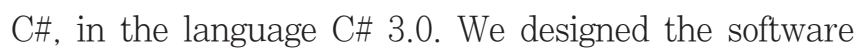
within .Net Framework 3.5, and used a graphical user interface development environment to produce an application formatted for Windows XP or higher versions. Two expert software engineers in the medical field participated in this process.

\section{RESULTS}

\section{Questionnaire}

We received responses from 98 of the 228 institutes (43.4\%) that we visited for the survey during 2 weeks in May 2017. Specific respondents were as follows: 72 clinical laboratory technologists (73.5\%), 18 nurses (18.3\%), four doctors (4.1\%), and four non-respondents (4.1\%). Of the 98 institutes that responded, 73 were clinics $(74.5 \%)$ and 24 were hospitals $(24.5 \%)$. One institute did not provide this information.

\section{1) General information}

Among the clinics with a small laboratory, the medical specialties were occupied as follows, in descending order of frequency: internal medicine $(61.6 \%)$, orthopedic surgery and neurology (each 6.8\%), urology (4.1\%), general surgery (2.7\%), and others. For the hospitals, the first and second ranked specialties were the same as for clinics (internal medicine, 95.8\%; orthopedic surgery, 58.3\%). From the third rank on, however, medical specialty differed: anesthesiology (25.0\%), general surgery (20.8\%), neurosurgery and radiology (each $12.5 \%$ ), family medicine $(8.3 \%)$, and others.

Regarding the electronic medical record (EMR) systems used, Ysarang (UBcare, Seoul, Korea) was the most common, used by 74 institutes (78.7\%). Other institutes used Dr. Brain (Brain Consulting, Seoul, Korea) (5.4\%), Phoenix (Ginus, Seoul, Korea), and eGHIS (MCC, Seoul, Korea) (each 2.7\%). For 79 of the 91 institutes (86.8\%), test results automatically interfaced with the EMR system. For the rest, the test results were input into the EMR system manually. 


\section{Journal of LABORATORY MEDICINE and QUALITY ASSURANCE}

Jae Han Kim et al • Quality Control Status of Small-Scale Laboratories

\section{2) Laboratory size}

We classified the clinics and hospitals into subclasses based on the average number of tests per month. Approximately half (46.5\%) of the clinics performed $>100$ to $<500$ tests per month, and more than half of these tests were for the hematology and chemistry sections of the laboratory. More than half the hospitals (52.2\%) performed $>500$ tests per month. Besides the hematology and chemistry sections, these laboratories performed tests in the urinalysis, electrolyte, immunology, and coagulation sections. When comparing equivalent groups in terms of number of monthly tests between clinics and hospitals, hospitals operated more inspection sections and equipment than those of the clinics. However, the average number of clinical laboratory technologists did not significantly differ between the two types of institutions (Table 1).

\section{3) Status of external quality assessment}

A total of 89 institutes responded to the questions on external quality assessment (EQA). Thirty-three percent (22 out of 66) of the clinics and 52\% (12 of 23) of the hospitals answered that they performed EQA. While the primary method of EQA in clinics was peer comparison, hospitals mainly participated in the domestic proficiency testing program (Table 2).

\section{4) Status of internal quality assessment}

The respondents of 73\% (66 out of 90) of institutes answered that they utilized internal quality assessment (IQA) for self-management of quality in their laboratories. The status of IQA in these 66 institutes (including 44 clinics and 22 hospitals) is detailed in Table 3. The majority of institutes conducted internal QC using commercialized QC materials. However, only $52 \%$ of the clinics and $23 \%$ of the hospitals used their own acceptable ranges, rather than the manufacturer's expected range. The overall percentage of manual QC management was $52 \%$ for clinics and $82 \%$ for hospitals. Here, we defined manual QC management as manually entering the QC results into the QC software or simply printing and storing QC results from the equipment (Table 3).

\section{5) Actual obstacles to correcting internal quality assessment}

The barriers to performing IQA for clinics are listed as follows, in order of perceived importance: high cost, work complexity, insufficient workforce, time shortage, and lack of a proper QC software program. The barriers faced by hospitals were almost identical to those faced by clinics, except that insufficient workforce was considered more important than work complexity (Table 4).

\section{6) Preferences for free quality control software}

When asked if they would like to use free QC software, 31 of the 61 clinics $(50.8 \%)$ and 16 of the 22 hospitals (72.7\%) answered "yes." They suggested the following features as essential for free QC software: simple and

Table 1. The size of the clinical laboratories of the surveyed institutes

\begin{tabular}{lccccc}
\hline Variable & $\begin{array}{c}\text { No. of } \\
\text { institutes (\%) }\end{array}$ & $\begin{array}{c}\text { No. of } \\
\text { monthly tests }\end{array}$ & $\begin{array}{c}\text { No. of } \\
\text { instruments }\end{array}$ & Sections ${ }^{*}$ & $\begin{array}{c}\text { No. of clinical laboratory } \\
\text { technologist }\end{array}$ \\
\hline Clinics (n=71) & $14(19.7)$ & 1 to $<50$ & $1.4 \pm 0.9$ & HA & $1.0 \pm 0.0$ \\
& $13(18.3)$ & 50 to $<100$ & $1.8 \pm 0.4$ & HA, CM & HA, CM \\
& $33(46.5)$ & 100 to $<500$ & $2.8 \pm 1.2$ & HA, CM, UA & $1.1 \pm 0.4$ \\
Hospitals (n=23) & $11(15.5)$ & $\geq 500$ & $2.9 \pm 1.1$ & & $1.1 \pm 0.3$ \\
& $3(13.0)$ & 50 to $<100$ & $3.7 \pm 1.5$ & HA, CM, UA, ET & $1.3 \pm 0.6$ \\
& $8(34.8)$ & 100 to $<500$ & $3.3 \pm 2.0$ & HA, CM, UA, ET, IM & $1.2 \pm 0.4$ \\
\hline
\end{tabular}

Abbreviations: HA, hematology; CM, chemistry; UA, urinalysis; ET, rlectrolyte; IM, immunology; CA, voagulation.

${ }^{\star}$ Performed in at least half of the institutes in each group. 


\section{Journal of LABORATORY MEDICINE and QUALITY ASSURANCE}

Jae Han Kim et al • Quality Control Status of Small-Scale Laboratories

Table 2. The status of external quality assessment according to the number of tests

\begin{tabular}{|c|c|c|c|c|c|}
\hline \multirow{2}{*}{ Variable } & \multirow{2}{*}{ EQA rate } & \multirow{2}{*}{$\begin{array}{l}\text { No. of monthly } \\
\text { tests }\end{array}$} & \multirow{2}{*}{$\begin{array}{l}\text { Managed test } \\
\text { proportion }\end{array}$} & \multicolumn{2}{|c|}{ EQA method } \\
\hline & & & & Proficiency testing & Peer comparison \\
\hline \multicolumn{6}{|c|}{ Clinics $(n=22)$} \\
\hline & $0(0 / 14)$ & 1 to $<50$ & & & \\
\hline & $25(3 / 8)$ & 50 to $<100$ & $1-100$ & $33(1 / 3)$ & $67(2 / 3)$ \\
\hline & $36(12 / 33)$ & 100 to $<500$ & $1-100$ & $18(2 / 11)$ & $81(9 / 11)$ \\
\hline & $64(7 / 11)$ & $\geq 500$ & $26-100$ & $57(4 / 7)$ & $43(3 / 7)$ \\
\hline Total & $33(22 / 66)$ & & & $33(7 / 21)$ & $67(14 / 21)$ \\
\hline \multicolumn{6}{|c|}{ Hospitals $(n=12)$} \\
\hline & $67(2 / 3)$ & 50 to $<100$ & $76-100$ & $50(1 / 2)$ & $50(1 / 2)$ \\
\hline & $75(6 / 8)$ & 100 to $<500$ & $51-100$ & $66(4 / 6)^{\dagger}$ & $33(2 / 6)$ \\
\hline & $33(4 / 12)$ & $\geq 500$ & $1-75$ & $75(3 / 4)^{\dagger}$ & $25(1 / 4)$ \\
\hline Total & $52(12 / 23)$ & & & $67(8 / 12)$ & $33(4 / 12)$ \\
\hline
\end{tabular}

Values are presented as application \% (number of "yes" responses/total number of respondents) or range \%, unless otherwise stated.

Abbreviation: EQA, external quality assessment.

${ }^{*}$ Whole range of response in terms of percentage of EQA performed in the entire test. ${ }^{\dagger}$ Including one institute that performed this simultaneously with peer comparison.

Table 3. The status of internal quality assessments according to the number of tests

\begin{tabular}{|c|c|c|c|c|c|c|c|}
\hline \multirow{2}{*}{ Variable } & \multicolumn{4}{|c|}{ Clinics $(n=44)$} & \multicolumn{3}{|c|}{ Hospitals $(n=22)$} \\
\hline & 1 to $<50$ & 50 to $<100$ & 100 to $<500$ & $\geq 500$ & 50 to $<100$ & 100 to $<500$ & $\geq 500$ \\
\hline Self-designed guidelines & $21(3 / 14)$ & $50(5 / 10)$ & $75(25 / 32)$ & $100(11 / 11)$ & $100(3 / 3)$ & $88(7 / 8)$ & $100(12 / 12)$ \\
\hline Commercialized QC materials & $67(2 / 3)$ & $100(5 / 5)$ & $96(24 / 25)$ & $100(11 / 11)$ & $100(3 / 3)$ & $86(6 / 7)$ & $92(11 / 12)$ \\
\hline Self-set QC limits & $0(0 / 3)$ & $40(2 / 5)$ & $40(10 / 25)$ & $100(11 / 11)$ & $67(2 / 3)$ & $29(2 / 7)$ & $18(1 / 12)$ \\
\hline \multicolumn{8}{|l|}{ QC software } \\
\hline Commercial product & $33(1 / 3)$ & $20(1 / 5)$ & $41(9 / 22)$ & $27(3 / 11)$ & & $29(2 / 7)$ & $8(1 / 12)$ \\
\hline Laboratory development & & $40(2 / 5)$ & $50(11 / 22)$ & & & $14(1 / 7)$ & $8(1 / 12)$ \\
\hline Excel program & & $20(1 / 5)$ & $9(2 / 22)$ & $55(6 / 11)$ & $100(2 / 2)$ & $43(3 / 7)$ & $75(9 / 12)$ \\
\hline Other & $33(1 / 3)$ & $20(1 / 5)$ & & $18(2 / 11)$ & & $14(1 / 7)$ & $8(1 / 12)$ \\
\hline Manual QC management & $67(2 / 3)$ & $40(2 / 5)$ & $52(13 / 25)$ & $55(6 / 11)$ & $100(2 / 2)$ & $100(7 / 7)$ & $75(9 / 12)$ \\
\hline
\end{tabular}

Values are presented as application \% (number of "yes" responses/total number of respondents).

Abbreviation: QC, quality control.

Table 4. Practical obstacles in internal quality assessment

\begin{tabular}{lcc}
\hline \multicolumn{1}{c}{ Barrier } & Clinics $(\mathbf{n}=62)$ & Hospitals $(\mathbf{n}=\mathbf{2 3})$ \\
\hline Cost burden & $30(48.4)$ & $18(78.3)$ \\
Insufficient workforce & $16(25.8)$ & $8(34.8)$ \\
Time shortage & $12(19.4)$ & $6(26.1)$ \\
Work complexity & $20(32.3)$ & $5(21.7)$ \\
Absence of programs & $11(17.7)$ & $3(13.0)$ \\
Other & $5(8.1)$ & $2(8.7)$ \\
\hline
\end{tabular}

Values are presented as number (\%). easy to use, interface displaying $\mathrm{QC}$ results, automatic judgment according to Westgard multiple rules, help with corrective action, Levy-Jennings charts with outliers highlighted, statistical calculations (means, standard deviations, coefficient variations), ability to set self-control limits, and generation and printing of QC reports.

\section{New Internal Quality Control Software}

From October 2016 to February 2017, we planned the development of a new program and prepared the 


\section{Journal of LABORATORY MEDICINE and QUALITY ASSURANCE}

Jae Han Kim et al • Quality Control Status of Small-Scale Laboratories

necessary environment for it. Then, over the second half of 2017, we created new QC software called SmartQC ver. 1.0 (U2Bio Co. Ltd., Seoul, Korea).

\section{1) SmartQC installation}

(1) Install the Microsoft SQL Server 2008 R2 SP2 (Express Edition) and set up the network (https:// www.microsoft.com/ko-kr/download/details. aspx?id=30438).

(2) Configure the PC Firewall using the New Inbound Rule Wizard.

(3) Download the SmartQC software (http://www. lab2gene.co.kr/Contents/Customer/NoticeList. aspx? categoryID $=5$ ).

(4) Run the following file: LaboratoryGatewayIILauncher. exe $\rightarrow$ DBRestore.exe.

(5) Check the server information on connection by pressing the (Log in) button.

(6) Create an account after logging in using the default ID and password (smartqc/smartqc).

(7) Input the basic inspection information such as the instrument, analyte, and QC materials.

For more information, installation and operating manuals can be downloaded from the SmartQC software website. If the instrument's QC raw data is linked to the SmartQC software, almost all IQA tasks can be run on the computer.

\section{2) Basic functions}

The Basic Data menu of the SmartQC program has several specific functions, such as user manager, inspection manager, QC material manager, instrument manager, and department manager (Fig. 1). The QC lot manager menu allows users to manage the names of materials, lot numbers, expiration data, and the expected ranges for $\mathrm{QC}$ materials. In the Daily Task menu, daily QC results for each level are recorded numerically, plotted as a Levy-Jennings chart, and judged using the Westgard multiple rules. It is also possible to set a temporary and formal QC allowable range for each laboratory and to output the results as a report. Two review reports can be generated in both Microsoft Excel and PDF formats: monthly QC statistics per test item and a monthly precision trend of all items per instrument. Additional advantages of this software are that it will be continuously updated by IT specialists and can link QC results with instruments via installation of the interface program.

\section{DISCUSSION}

Many of the institutes in this study operated the medical specialties of internal medicine or orthopedic surgery, and the laboratories primarily ran tests in the hematology and chemistry sections. There was a trend for hospitals to run more tests, more inspection sections, and to have more instruments than clinics, even though the number of

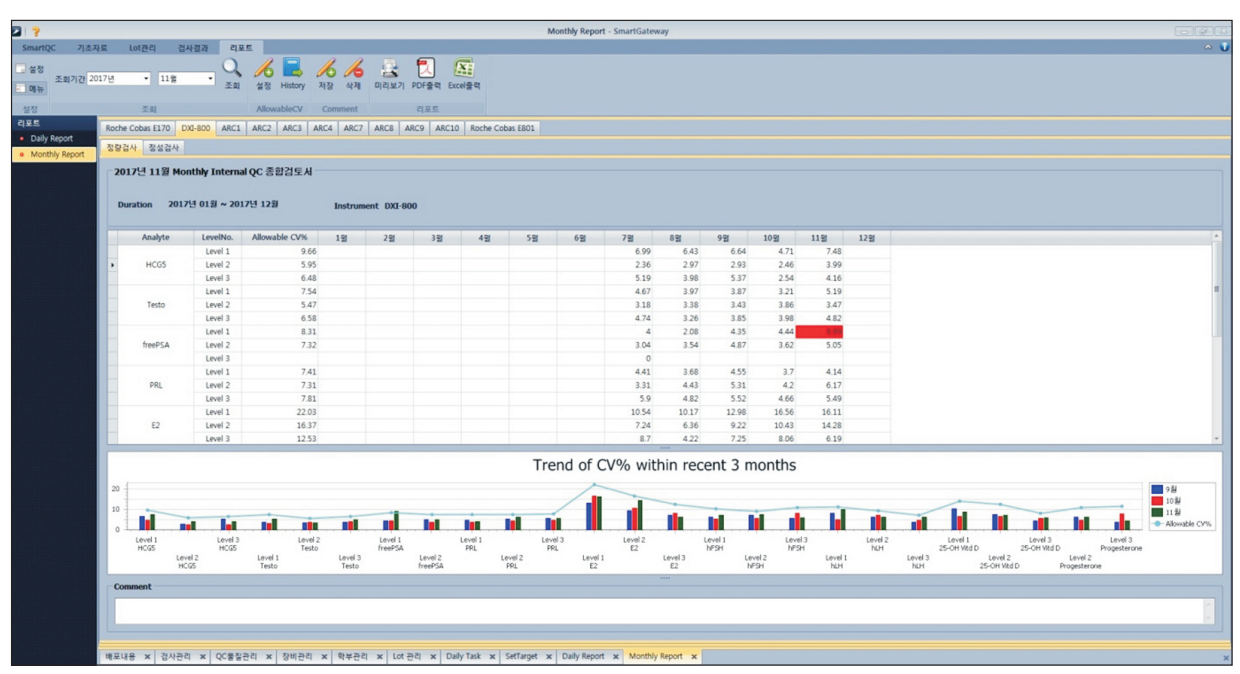

www.jlmqa.org $\quad J$ Lab Med Qual Assur 2018;40:101-108
Fig. 1. Screenshot of the SmartQC software. Five different menu tabs are provided, as follows: SmartQC (user manager), basic data (inspection manager, QC material manager, instrument manager, and department manager), QC lot manager, test results (daily task and target manager), and report (daily report and monthly report). Abbreviation: QC, quality control. 


\section{Journal of LABORATORY MEDICINE and QUALITY ASSURANCE}

Jae Han Kim et al • Quality Control Status of Small-Scale Laboratories

monthly tests was similar overall. The number of clinical laboratory technologists did not significantly differ between clinics and hospitals, suggesting that hospitals tend to manage staff tightly.

Both clinics and hospitals commonly had low EQA rates, suggesting that the accuracy of QC tests is not regularly verified. For small-scale laboratories, it might be necessary to first recommend periodic peer comparisons to increase EQA rates [2]. This is because peer comparison tests do not require an additional participation fee, and the procedure and analysis are not complicated. When using commercialized QC materials, laboratories can participate in peer comparison programs provided by QC material manufacturers as an alternative EQA procedure [4].

As for IQA, many of the institutes (48\% of clinics and $77 \%$ of hospitals) use the expert ranges given on manufacturers' assay sheets and do not create their own acceptable ranges for QC results. Manufacturer ranges might be too broad to detect problems during inspections of individual laboratories [5]. According to the results of the 2017 QC Practices Survey, conducted by Westgard QC, 43.1\% of 701 laboratories across the world and $32.1 \%$ of the 271 US laboratories used manufacturer ranges listed on package inserts as expected ranges [6,7]. Furthermore, among these respondents, public health or government laboratories and reference laboratories constituted around $56.0 \%$ of the global labs and $32.2 \%$ of the US labs. If respondents of private hospital labs and outpatient clinic labs are analyzed separately, we might assume that the usage of manufacturer ranges will be higher. Accordingly, we can perhaps conclude that the results for the clinics in this study do not significantly differ for the United States or even the world. However, the percentage of hospitals that used the manufacturer range was much higher compared to that of the clinics. This is presumably because of the insufficient workforce in proportion to the number of tests or inspection sections, such that only basic QC tasks were performed.

In addition, the proportion of institutes that manually managed the QC results was well over half of the total. Manual management makes it difficult to perform
IQA correctly and thoroughly. We identified a need for continued improvement in overcoming practical barriers to QC in small laboratories. However, major structural obstacles such as cost, workforce, and time problems are difficult to solve quickly. The complexity of the QC tasks is expected to be gradually resolved through education, because insurance policies in South Korea have begun mandating the completion of quality management training for institutes without full-time specialists in anatomic pathology. The lack of appropriate QC software has been regarded as less important compared to other factors. However, providing new QC software that can alleviate the burden of other obstacles might be practically helpful for managing the internal quality of small laboratories.

We obtained basic data on the current status of external and internal QC in small-scale laboratories through this survey. The accuracy of this survey is limited because respondents might have been reluctant to disclose the QC status of the laboratory and understanding of the questions might have been somewhat different depending on the respondent's job type. If this kind of survey is mandated and continued by the relevant agency, we expect that it will help to bring about improvements in QC in small laboratories. We expect that these data will be helpful in identifying problems in QC procedures and improving small-scale laboratories. Furthermore, we developed a new QC software specifically for these laboratories for improving QC.

\section{ACKNOWLEDGEMENTS}

This work was supported by the 2017 Academic Research Fund of the Korean Association of Quality Assurance for Clinical Laboratories (survey research, assignment number 2017-06).

\section{REFERENCES}

1. Forsman RW. Why is the laboratory an afterthought for managed care organizations? Clin Chem 1996;42:813-6.

2. Westgard JO. Basic QC practices: training in statistical 


\section{Journal of LABORATORY MEDICINE and QUALITY ASSURANCE}

Jae Han Kim et al • Quality Control Status of Small-Scale Laboratories

quality control for medical laboratories. 3rd ed. Paju: Koonja, 2012.

3. Korea Laboratory Medicine Foundation. KLAP accreditation checklist: 2017 edition. http://lmf.or.kr/sub/catalog. php?CatNo=65 (Accessed May 29, 2017).

4. Clinical and Laboratory Standards Institute. QMS24: using proficiency testing and alternative assessment to improve medical laboratory quality. 3rd ed. Wayne (PA): Clinical and Laboratory Standards Institute, 2016.

5. Westgard QC. Survey of US labs' QC practices: the great global QC survey: results from US laboratories. https:// www.westgard.com/great-global-qc-survey-us-results. html (Accessed December 19, 2017).

6. Westgard QC. 2017 Global QC practices survey all results. https://www.westgard.com/downloads/metricsand-data-downloads/79-2017-global-qc-practicessurvey-all-results.html (Accessed December 19, 2017).

7. Clinical and Laboratory Standards Institute. C24-ED4: statistical quality control for quantitative measurement procedures: principles and definitions. 4 th ed. Wayne (PA): Clinical and Laboratory Standards Institute, 2016. 
Journal of LABORATORY MEDICINE and QUALITY ASSURANCE

Jae Han Kim et al • Quality Control Status of Small-Scale Laboratories

병·의원 내 소규모 검사실의 정도관리 실태조사 및 해결안 모색

김재한 ${ }^{1}$ - 최은진 ${ }^{1} \cdot$ 황규현 $^{2} \cdot$ 이재호 $^{2} \cdot$ 한미순 $^{1}$

1장원의료재단 유투의원 진단검사의학과, ${ }^{2}$ (주)유투바이오 IT 연구소

배경: 의학적으로 중요한 오류를 방지하기 위해 의료기관의 검사실에서는 철저하게 통계적인 정도 관리 절차를 수행해야 한다. 우리는 소규모 검사실의 정도관리 실태를 조사하고, 이들의 정도관리 개선을 위해 쉽게 사용할 수 있는 새로운 통계적 정도관리프로그램를 개발하였다.

방법: 외부와 내부정도관리 실태를 묻는 설문지를 제작하여 소규모 검사실이 있는 병원 및 의원에 설문조사를 요청하였다. 또한 무료로 다운로드하여 설치만 하면 손쉽게 사용할 수 있는 정도관리 소프트웨어를 개발하였다.

결과: 의원의 $32 \%$ (66기관 중 22처)와 병원의 $52 \%$ (23기관 중 12처)에서 외부정도관리를 수행하 고 있었다. 해당 문항에 답한 기관의 $73 \%$ (90기관 중 66처)는 내부정도관리에 대한 내부 지침이 있 으며 이를 위해 상업화된 정도관리물질을 사용하고 있었다. 그러나 의원의 $52 \%$ 와 병원의 $23 \%$ 만 이 제조사가 제시한 허용범위 대신 자체 설정한 허용범위를 사용하고 있었다. 또한 의원 52\%, 병원 $82 \%$ 에서 정도관리 측정값을 수기로 관리하고 있었다. 정도관리 업무에 있어 이러한 문제점을 개선 할 수 있도록 우리는 통계적 정도관리의 모든 기본 기능을 전산화시킬 수 있는 새로운 정도관리프 로그램을 개발하였다.

결론: 설문조사를 통해 소규모 검사실의 외부 및 내부정도관리 현황에 대한 기초 자료를 얻었다. 더 나아가 우리는 새로 개발된 정도관리프로그램이 소규모 검사실의 정도관리 질을 개선하는 데 실제적인 도움이 될 것이라고 제안한다.

(J Lab Med Qual Assur 2018;40:101-108)

교신저자: 한미순

우) 05755 서울시 송파구 거마로 68 , 장원의료재단 유투의원 진단검사의학과

Tel: 02)910-2103, Fax: 02)910-2190, E-mail: loveelohim9083@hanmail.net 